\title{
DETERMINANTS OF SHARIAH BANKS LENDING: EVIDENCE FROM ISLAMIC BUSINESS UNIT BANKS
}

\author{
Azwirman $^{1}$ \& Hamdi Agustin ${ }^{2}$ \\ ${ }^{1 \& 2}$ Fakultas Ekonomi (FE), Universitas Islam Riau (UIR) \\ Email: azwirman2016@eco.uir.ac.id, hamdiagustin@eco.uir.ac.id
}

\begin{abstract}
ABSTRAK
Tujuan penelitian ini adalah untuk menganalisis pengaruh inflasi, Sertifikat Bank Indonesia Syariah (SBIS), Dana Deposito (Deposit Fund/DF), dan Kredit Bermasalah (Non Performing Financing/NPF) terhadap Pinjaman Murabahah. Populasi dan sampel ini terdiri atas 22 unit usaha syariah, hanya 10 bank yang dipilih untuk dijadikan sebagai sampel. Periode penelitian ini yaitu dari tahun 2011 sampai tahun 2015. Penelitian ini menggunakan data panel dan metode kuadrat terkecil (Ordinary Least Squares/OLS). Hasil penelitian menunjukkan bahwa Sertifikat Bank Indonesia Syariah memiliki pengaruh negatif terhadap Pinjaman Murabahah. Hal ini mengungkapkan bahwa bank memiliki penyebaran suku bunga yang juga menunjukkan pengaruhnya terhadap perilaku melakukan pinjaman. Hal tersebut merupakan salah satu instrumen untuk menyimpan dana di Bank Indonesia yang digunakan untuk menyerap likuiditas berlebih pada bank Islam dalam konteks operasi pasar terbuka untuk mengendalikan jumlah peredaran uang. Dana deposito memiliki pengaruh positif terhadap Pinjaman Murabahah. Hal ini mengungkapkan bahwa deposito yang diterima oleh bank adalah bentuk permintaan yang dapat dibayarkan kembali ke penyetor/deposan sesuai permintaan. Oleh sebab itu, bank dapat mempertahankan jumlah deposito nasabah yang besar sebagai persediaan untuk memenuhi permintaan nasabah daripada memberikan pinjaman. Kredit bermasalah (NPF) memiliki pengaruh negatif terhadap Pinjaman Murabahah. Hasil ini menggambarkan bahwa kredit bermasalah (Non performing finance) yang lebih tinggi diikuti dengan penurunan pada penyebaran dana yang dibuat oleh Bank untuk mengurangi resiko kredit macet.
\end{abstract}

Kata Kunci : Pinjaman Murabahah, Unit Usaha Syariah, Sertifikat Bank Indonesia Syariah.

\section{ABSTRACT}

The purpose of this research to analyze the effects of inflation, Certificates of Indonesian Bank of Sharia (CIBS), deposit funds (DF) and Non Performing Financing (NPF) to murabahah lending. The population and sample consists of 22 Islamic business units, only 10 banks were selected to be the sample. The period of this studies from2011to2015.This study using panel data and using pooled Ordinary Least Squares (OLS).The results showed that Certificates of Indonesian Bank of Sharia has a negative effect on murabahah lending. This suggests that banks have a greater Bank interest rate spread that has also been shown to affect to lending behavior. it is one of the instruments for placing funds at Bank Indonesia which is used to absorb the excess liquidity of Islamic banks in the context of open market operations to control the amount of money in circulation. Deposit funds have a positive effect on murabahah lending. This suggests that deposits what a bank accepts are demand forms which are repayable to depositors on demand. As a result banks may maintain a large amount of customer deposits as a reserve to meet customers demand instead of lending. NPF has a negative effect on ML These results illustrate that the higher Non performing finance is followed by a decrease in the distribution of funds made by the Bank to reduce the risk of bad credit.

Keywords : Murabahah Lending, Islamic Business Units, Certificates of Indonesian Bank of Shariah. 


\section{INTRODUCTION}

The extent of literature on Islamic banking divided into theoretical and empirical dimension. The earliest works dealing with the potential of Islamic banking include Mannan (1968), Ahmad (1987), Saeed (1996), Iqbal and Mirakhor (1999). These authors discussed a wide range of institutional issues including concepts and principles that are subject to interpretation. Due to the rapid growth in Islamic banking in these recent decades, it calls for opportunities for the academics to conduct study in analyzing its' financial performance using financial ratios. Some previous studies investigated performance of Islamic Banks and compare it with conventional banks performance (Samad, 1999; Samad and Hassan, 2000; Iqbal, 2001; Rosly and Bakar, 2003; Samad, 2004; Kader et. al, 2007; Widagdo and Ika; 2007; Beck et al., 2010; Jaffar and Manarvi, 2011; Ansari and Rehman, 2011; Wahidudin at al., 2012; Merchant, 2012; Zeitun, 2012; Babatunde and Olaitan, 2013).

The banks have over the years come up with innovative ways of dealing with the credit risk which apparently is the oldest but most demanding for commercial banks. This risk originates from the chances that a borrowing client will not honor the debt obligations, thereby placing the bank's capital in jeopardy. This concern has led to a lot of effort being put towards managing the bank's exposure to credit risk, with the most notable attempt being the Basel-II accord which was later revised to BaselIII. The Basel guiding principle is to entrench a strict culture of managing inherent credit risk by commercial banks internationally.

The banking industry is one critical component of the financial system in developing countries capable of facilitating capital accumulation and economic processes. This is possible through efficient financial intermediation. The banks mobilize funds from the surplus spending units in order to bring financial costs down. Banks mostly transform liquid assets like deposits into illiquid assets like lending. This transformational process of banks' activity is at best influenced by a host of factors, namely, macroeconomic, bank level (Peek and Rosengreen, 1995) and industry level characteristics (Boot and Thakor, 2000). Boot and Thakor (2000) indicate that the level of banking industry competition greatly influences bank lending strategy positively. Again, Kashyap and Stein (2000), find a strong case that in situations where a bank is handicapped in terms of credit, it will only take the bank capital to measure its ability of lending.

Lending is undeniably the heart of banking business (Adedoyin and Sobodun, 1996). Granting loans and advance for the borrower is the main activity that generates income for banks highly. Therefore, loan portfolio is typically the largest asset and source of revenue for banks. However, lending and advance is the most profitable and liquid asset for the bank to maintain its maximum liquidity obligation to their depositors or lenders; banks do not invest its entire fund in a profitable asset (Nwankwo, 2000).

Bank accept customer deposits and use that fund to grant loans to borrowers or invest in other assets that will yield a return higher than the amount bank pays the depositor (McCarthy et al., 2010). It is understandable that, the main source of lending is deposit or money accepted from the depositor but the amount that would have to be lent is a certain percentage of the total deposited amount and the remaining is kept as a reserve for the purpose of maintaining its liquidity. 
Lending is a major service rendered by banks which contributes immensely to their revenue generation. The loans can either be in short term, medium and/or long term form basis depending on the type of need being addressed. Lending is therefore a major driver in aiding the economic activities of households, firms and governments which has a bearing on the economic growth and development of any nation. Thus, economic growth is generated through banks' lending activities which provide resources for real investment.

Commercial banks play a very important role of savings mobilization and financial resource allocation which makes them play a critical role in the growth of an economy and its development. It needs to be noted that the banks have capacity to mobilize resources and allocating the same to investments ventures which are productive.

The business of banking is so sensitive by virtue that most of its revenue is generated from lending activities. The lending process may expose the bank to high risk that may lead to a loss. Therefore, it is imperative for banks' executives to understand the determinants of lending behavior otherwise good bank performance or profit would be improbable.

The financial intermediation role that is played by the commercial banks is critical in spurring economic growth and development of any nation. Through the intermediation process, banks are able to aggregate deposits which are in turn used to finance the various sectors of economy. Poor lending practices will lead to banks incurring heavy losses which could see such players collapse. This might have a ripple effect in the economy which might lead to a total collapse of the banking sector.
In Indonesia, Inflation fluctuated from $3.80 \%$ in 2011 to $3.40 \%$ in 2015 which indicated an increase in prices in general and would reduce people's purchasing power which should also reduce demand for murabahah financing. However, the opposite happened to murabahah financing which continued to increase in the same year. Value of Certificates of Indonesian Bank of Sharia (CIBS) has increased every year, although in 2015 it has decreased but the figure is not much different from the previous year, meaning the role of SBIS as a monetary policy instrument that aims to overcome the difficulties and excess liquidity in banks that operate with sharia principles effective.

Deposit funds in 2011-2015 continued to increase. Even though in 2012 there was a decrease in your economy in the following years, it continued to increase. This is indicated by the amount of deposit funds in 2012 amounting to $16,382,620$ billion rupiah while in 2015 it reached 26,728,131 billion rupiah. This reflects that slowly the existence of murabahah financing is increasingly in demand by the public. The Non Performing Financing (NPF) variable also fluctuated, which was down from 2011 amounting to $4.279 \%$ with the total financing disbursed amounting to 56,365 Billion rupiahs and down in 2012 to $3.849 \%$ with total financing disbursing 88,004 Billion rupiahs. It show NPF does not always negatively affect murabahah lending.

The Islamic banking industry in developing countries such as Indonesia in particular forms a strategic of the financial system. The existing literature does not provide adequate empirical evidence on the lending of Islamic banks in developing economies like Indonesia. Despite having witnessed an impressive profitability era, which was characterized by stiff competition, massive deposits and wide 
investment opportunities by Indonesia Islamic banks, it has been noted that some banks tend to ignore the reality that their administration should be anchored on specialized skills and dexterity on the part of their management. In a case where a bank grants credit facility in disregard to its liquidity position, then it may run into trouble in meeting its customers cash drawings on demand. Poor loan service will impact negatively to its profitability and consequently the level of its liquidity.

In previous literature, a lot of work is done on determining the factors which influence the bank lending in Indonesia. But a little work is done on of Islamic banks business unit, So, the main purpose of this study is to fill this gap by bank lending of Islamic banks business unit that which factors have significant influence on murabahah lending during the period of 2011-2015. The Islamic banks have recently reported an upsurge of nonperforming loans. The study therefore sought to investigate what determines the murabahah lending of Islamic banks business unit by investigating the extent to which inflation, Certificates of Indonesian Bank of Sharia, deposit funds, and Non Performing Financing (NPF) to murabahah lending.

\section{LITERATURE REVIEW}

\section{Theory of Delegated Monitoring of Borrowers}

Monitoring of borrowers by banks relate to gathering of information during the loan appraisal process and post loan disbursements. It involves checking whether the borrower has fulfilled the lending requirements of the bank, screening the borrower to find out his creditworthiness and post deal tracking to ensure that all the covenants are adhered to. In cases where the banks operate client's transactional accounts, they tend to have privileged information in terms of the cash flows and expenditure. This privileged information comes in handy in the cases of small and medium business.

Financial efficiency in the banking sector has been highlighted as a requirement for growth of economy. This explains why a lot of emphasis is placed on continued research on this area. This is further informed by change in the banking industry which is characterized by stiff competition. Increased globalization and financial deregulation have ushered in era of new competition to the local banking which has seen considerable banks diversifying their operations to keep in pace with the current trend. The banks have since seen information technology providing varied opportunities for developing new nontraditional banking products and enhancing their distribution channels, for example internet and mobile bank platforms. This has led to reduced branch infrastructure investment.

\section{Loan Pricing Theory}

It's not practical for banks to always offer very low interest on deposits but at the same time offering high interest on loans so to maximize on their revenues. Banks ought to consider the problem of moral hazard and adverse selection in their attempt to maximize on revenue since it's hard to focus borrower type with certainty at the time of initiating client relationship. High interest rate might trigger adverse selection problem since the high rates will be mostly acceptable to the high risk borrowers. Once these categories of borrowers receive the loans, it's highly likely that they may develop moral hazard behavior as a result of venturing into high risky projects and investments (Chodechai, 2004). It's a common occurrence in most cases where the interest rate charged by banks does not mirror the risk profile of the borrowers.

\section{Empirical Literature Review}

Credit risk is critical since the default of a small number of important 
customers can generate large losses which can lead to insolvency (Bessis, 2002). Variation in credit risk may reflect a change in the health of a bank's loan portfolio (Cooper et al., 2003), which in turn may influence the performance of the institution. Lending is the primary functions of banks, and precisely assessing a borrower's credit worthiness has always been the only method of lending successfully (Andrew F., 2004). More financial institutions are exposed to high risk loan sand the higher accumulation of unpaid loans. Implying that, these loan losses have produced lower returns to many commercial banks (Miller and Noulas, 1997). Chodechai (2004) further stressed that, banks' lending decisions influenced by the past relationship with the borrowers, which enables to have more accurate understanding of the borrower's business and financial situation.

According to Mc Carthy et al. (2010) Customers' deposit is the primary source of bank loan. And thereby, deposits directly have a positive effect on lending. Moreover, Sebastian (2009) strongly reveal that, demand deposit liabilities had the most significant and positive influence on banks' credit allocations in Nigeria case. Generally, lending is the main means of income and the most profitable asset for the bank which is determined by bank size, credit risk, liquidity, cash required reserve, deposit, Investment, interest rate and gross domestic product. Literature reveals mixed results concerning to the relationship between commercial bank lending and these expected factors. Despite its mixed results most of the finding reveals a positive association between bank size, credit risk, deposit, gross domestic product and bank lending while investment and interest rate negatively associate it. However, the effect of cash required reserve on commercial bank lending falls under a serious argumentative issue. Some finding state that, cash required reserve reduce commercial bank credit; while others claim that, it encourage bank credit and the rest shows, no relation or its effect is insignificant. This lack of consensus among researchers requires further investigation; accordingly the researcher needs to look this issue in Indonesia context.

Research of Khodijah (2009) show that deposits fund negatively affect murabahah financing, Own Capital and Profit Margin have a positive and significant effect on murabahah financing, and NPF has a negative and significant effect on murabahah financing. Nurapriyani (2009) show that NPF has a negative and significant effect on murabahah financing, SWBI has a negative and significant effect on murabahah financing and conventional interest rates has a negative and significant effect on murabahah financing. Research of Nurjaya (2011) show that Inflation has a positive effect on murabahah financing, SBIS has a negative effect on murabahah financing, NPF has a positive effect on murabahah financing and deposits have a positive effect on murabahah financing.

Irina B. (2003), while assessing the exchange rates and liquidity of banks in Europe found out that high interest rates discourages people from accessing loans. On the other hand, Abdul Karim et al., (2011) while studying the effect of interest rates on credit creation by Malaysian banks also observed that there exists an inverse relationship with the bank lending volume. Tomak (2013) on the other hand in his study of the banks' size and market based variables such as inflation rate, interest rate, and GDP effect on the lending volume of banks in Turkey observed that the banks size, NPL level, inflation rate and asset quality all affect banks credit creation activities. Djiogap 
and Ngomsi (2012) used a sample of thirty five banks from six African countries to examine factors affecting the banks long term credit and concluded that the banks capitalization, availability of long term maturing liabilities, GDP growth and its size affect the ability of commercial banks to extend loans. These results recognized the value of a banks liquidity position in credit creation. Besides, Chernykh and Theodossiou (2011) postulated that the only determinant of credit creation by banks is its size, which simply refers to the banks capitalization and its assets.

Chodechai (2004) while researching on the elements that influence interest rates, collateral requirement and lending volume by banks observed that pricing decisions have to be taken with a lot of caution by banks. He also concluded that too low interest rates on loans may not compensate it from the charges on deposits, other associated expenses and loss given default. On the other hand too high interest rates may trigger the problem of moral hazard and adverse selection. Abd karim, Mohd, Adziz (2007) on the hand observed that tightening monetary policy instruments in Malaysia e.g. interest rate had an inverse relationship to lending decisions on all the sectors. Besides, they also noted out that interest rate exhibited a positive relationship with the Islamic loans but negative one with the conventional financing.

\section{RESEARCH METODH}

The population in this study as many as 22 Islamic banks business Unit but due to the limitations of the completeness of the data then the sample in this study 10 Islamic banks business Unit period 2011-2015. The data are taken from banks' annual reports. In this study using panel data and using pooled ordinary least square (OLS).The following model is estimated:

MLit $=\alpha+\beta 1$ CIBSit $+\beta 2$ DFit $+\beta 3$ NPFit + $\beta 4$ INFit $+\mathrm{e}$

Where i refer to the bank, $t$ refers to the years

ML : Murabahah lending

CIBS : Certificates of Indonesian Bank of Sharia

DF : deposit Fund

NPF : Non Performing Financing

INF : Inflation

\section{RESULT AND FINDING}

Table 1. Ordinary Least Square Result

\begin{tabular}{lll}
\hline Variable & \multicolumn{2}{c}{ ordinary least square } \\
\cline { 2 - 3 } Constan & Coef. & p-value \\
& 10.300 & $0.000 * * *$ \\
CIBS & -0.319 & $0.001 * * *$ \\
DF & 0.451 & $0.000 * * *$ \\
NPF & -0.056 & $0.004 * * *$ \\
INF & 0.043 & 0.295 \\
R-squared & 0.835 & \\
Adjusted R-squared & 0.697 & \\
Prob $>$ F & 0.0000 & \\
Number observation & 50 & \\
\multicolumn{2}{c}{$* * *$ and $* * *$ denote significance at the $10 \%, 5 \%$ and $1 \%$ level } \\
\multicolumn{2}{l}{ Source $:$ Data Processed $(2020)$}
\end{tabular}

The result of regression method above shows variable of CIBS, DF and
NPF have significant effect on ML. These results indicate that the two variables play 
a significant role in determining the level of ROA in sharia banks in Indonesia by $69.7 \%$.

CIBS has a negative effect on ML. This suggests that banks have a greater Bank interest rate spread that has also been shown to affect to lending behavior. Bank Indonesia Sharia Certificate (SBIS) is one of the instruments for placing funds at Bank Indonesia which is used to absorb the excess liquidity of Islamic banks in the context of Open Market Operations (OMOs) to control the amount of money in circulation. The Sharia Banking Statistics (SPS) data from 2013 to April 2017 shows an increase each year, CIBS continues to increase which results in a decline in the Islamic financing of business units. This shows that if there is an increase in CIBS, the reduced funds will be placed in the bank so that the deposit funds for financing are reduced. Thus the increase in CIBS reduces the amount of bank financing because they consider the placement of funds in CIBS to obtain a rate of return and a lower risk compared to the bank lending. Results of the study consistent of Chodechai (2004) Nurapriyani (2009), Nurjaya (2011), Abdkarim et al., (2011), Tomak (2013) and Khangalah (2016).

DF has a positive effect on ML. This suggests that deposits what a bank accepts are demand forms which are repayable to depositors on demand. As a result banks may maintain a large amount of customer deposits as a reserve to meet customers demand instead of lending. Banks in achieving their main objectives to obtain profits, of course, will always maximize the turnover of funds for productive sectors so that the bank will get maximum profits as well. This shows that Islamic banking performs its fund distribution function well because it continues to strive to encourage the growth of the real sector by increasing lending. Results of the study consistent of Nurjaya (2011).

NPF has a negative effect on ML These results illustrate that the higher NPF is followed by a decrease in the distribution of funds made by the Bank to reduce the risk of bad credit. This can be caused by several possibilities, even though the NPF in sharia banking is relatively small compared to conventional banking, which is still below the BI standard (5\% of Bank Indonesia), where conventional banks are more sensitive to derivative instruments. However, the Islamic banks business unit will be more sensitive if the real sector experiences a shock. Islamic banking is more active and tends to finance the business in the real sector in its fund distribution activities. Results of the study consistent of Nurapriyani (2009), Khodijah (2009) and Tomak (2013).

\section{CONCLUSION}

The population and sample consists of 22 Islamic business units, only 10 banks were selected to be the sample. The period of this study is from 2011 to 2015. Data are taken from the bank's annual reports. This study using panel data and using pooled Ordinary Least Squares (OLS). The results showed that Certificates of Indonesian Bank of Sharia, deposit funds and non performing financing influences to murabahah lending of Islamic business units. Meanwhile, inflation no influence to murabahah lending. Certificates of Indonesian Bank of Sharia has a negative effect on murabahah lending. This suggests that banks have a greater Bank interest rate spread that has also been shown to affect to lending behavior. it is one of the instruments for placing funds at Bank Indonesia which is used to absorb the excess liquidity of Islamic banks in the context of open market operations to control the amount of money in 
circulation. Deposit funds have a positive effect on murabahah lending. This suggests that deposits what a bank accepts are demand forms which are repayable to depositors on demand. As a result banks may maintain a large amount of customer deposits as a reserve to meet customers demand instead of lending. NPF has a negative effect on ML These results illustrate that the higher Non performing finance is followed by a decrease in the distribution of funds made by the Bank to reduce the risk of bad lending.

\section{REFERENCES}

Abd karim. M, Harif, M., \& Adziz. A. 2007. Monetary policy and sectoral Bank Lending in Malaysia. Global Economic Review, 35(3), 303-326.

Abdul karim. Z., Saini. A.W., \& Karim. A. B. 2011. Bank Lending Channels of Monetary Policy. Journal of Asian Pacific Business, 12(3), 225243.

Adedoyin \& Sobodun. 1996. Commercial Banks Lending Activities in Nigeria. Nigerian Financial Review, 9(3), 36 $-37$.

Ahmad, A. 1987. Development and Problems of Islamic Banks. Islamic Research and Training Institute. Islamic Development Bank. Jeddah.

Andrew F. 2004. Credit Risk Management Essential Capital Markets. Elsevier Butterworth heinemann press.

Ansari, A. \& Rehman, A. 2011. Financial Performance of Islamic and Conventional Banks In Pakistan: A Comparative Study. 8th International Conference on Islamic Economics and Finance - Doha.1 (1), 1-19.

Babatunde, O.A. \& Olaitan, O. A. 2013. The Performance of Conventional and Islamic Banks in The United Kingdom: A Comparative Analysis.
Journal of Research in Economics and International Finance, 2(2), 2938.

Beck, T., Demirgüç-Kunt, A. and Merrouche, O. 2010. Islamic vs. Conventional Banking: Business Model, Efficiency and Stability, Working Paper 5446 (WPS5446). The World Bank Development Research Group Finance and Private Sector Development Team.

Bessis, J. 2002. Risk Management in Banking (2nd ed.). John Wiley, Sons Ltd. London.

Boot, A. W. A. \& Thakor, A. V. 2000. Can Relationship Banking Survive Competition?. The Journal of Finance, 55(2).

Chernykh. L, \& Theodossiou. A. 2011. Determinants of Bank Long Term Lending Behavior: Evidence from Russia. Multinational Finance Journal, 15(1), 193-216.

Chodechai, S. 2004. Determinants of Bank Lending. An Empirical Examination for the years 1992 - 1996. Thailand.

Cooper, M., Jackson W., \& Patterson 2003. Evidence of Predictability in The Cross-Section of Bank Stock Returns. Journal of Banking and Finance, 27(1), 817-850.

Djogap. F., \& Ngomsi, A. 2012. Determinants of Bank Long Term Lending Behavior in The Central African Economic and Monetary Community (CEMAC). Review of Economic and Finance, 107-114.

Iqbal, M. 2001. Islamic and Conventional Banking in The Nineties: A Comparative Study. Islamic Economic Studies, 8(2), 1-28.

Iqbal, Z. \& Mirakhor, A. 1999. Progress and Challenges of Islamic banking. Thunderbird International Business Review, 41(4-5), 56-68. 
Irina. B. 2003. Bank Liquidity and Exchange Rate Regimes: New European Perspectives. 3rd international Scientific Conference. Bulgaria.

Jaffar, M. \& Manarvi, I. 2011. Performance Comparison Of Islamic and Conventional Banks in Pakistan. Global Journal of Management and Business Research, 11(1),59-66.

Kader, J.M., Asarpota, A.J., \& AlMaghaireh, A. 2007. Comparative Financial Performance of Islamic Banks vis-à-vis Conventional Banks in the UAE. Proceeding on Annual Student Research Symposium and the Chancellor's Undergraduate Research Award. retrievedhttp://sra. uaeu.ac.ae/CURA /Proceedings (May 31, 2007).

Kashyap, A., Rajan R., \& Stein J. 2000. Banks as Liquidity Providers: An Explanation for The Coexistence of Lending and Deposit Taking. Quarterly Journal of Economics, 113, 733-771.

Khangalah. M.O. 2016. Determinants of Commercial Banks Lending Behavior in Kenya: case of state owned banks in Kenya. Research Project Presented in Partial Fulfillment of the Requirement for Award of Masters Degree in Business Administration to School of Business, University of Nairobi.

Khodijah H. M. 2009. Pengaruh Simpanan Dana Pihak Ketiga, Modal Sendiri, Marjin Keuntungan dan NPF terhadap Pembiayaan murabahah pada Bank Syariah Mandiri. Skripsi, UIN Sunan Kalijaga Yogyakarta.

Mannan, M. A. 1968. Islam and Trend in Modern Banking: Theory and Practice of Interest Free Banking.
Islamic Review and Arab Affairs, 73-95.

McCarthy , M., Schneider D., \& Tibb S. 2010. Investments and Loans U.S Banks. Journal of Bank accounting and Finance,19-24.

Merchant, I. P. 2012. Empirical Study of Islamic Banks Versus Conventional Banks of GCC. Global Journal of Management and Business Research, 12(20), 33-41.

Miller, S., \& Noulas. 1997. Portfolio Mix and Large-Bank Profitability. USA.

Nurapriyani, D. 2009 Faktor-Faktor Yang Mempengaruhi Pembiayaan Murabahah Di Bank Syariah Mandiri Periode Tahun 2004 2007. Universitas Islam Negeri Sunan Kalijaga Yoyakarta.

Nurjaya, E, 2013. Analisis Pengaruh Inflasi, Sertifikat Bank Indonesia Syariah (SBIS), Non Performing Financing (NPF) Dan Dana Pihak Ketiga (DPK) Terhadap Pembiayaan Murabahah pada Bank Syariah di Indonesia. Universitas Islam Negeri Syarif Hidayatullah Jakarta.

Nwankwo, G.O. 2000. Organizing for Financial Risk Management. The Credit Administrator, 2 (2), 32-39.

Peek, J., \& Rosengren E., 1995. The Capital Crunch: Neither a Borrower nor a Lender be. Journal of Money, Credit, and Banking, 27, (3), 625638.

Rosly, S.A., \& Bakar, M.A.A. 2003. Performance of Islamic and Mainstream Banks in Malaysia. International Journal of Social Economics, 30 (12), 1249-1265.

Saeed, M . 1996. Islamic Banking and Interest. E.J. Brill, The Netherlands. 
Samad, A. 1999. Comparative Efficiency of the Islamic Bank Malaysia vis-àvis Conventional Banks. IIUM Journal of Economics and Management, 7 (1), 1-25.

Samad, A. 2004. Performance of Interest Free Islamic Banks vis-à-vis Interest-Based Conventional Banks of Bahrain. IIUM Journal of Economics and Management, 12 (2), 1-25.

Samad, A., \& Hassan, M. K. 2000. The performance of Malaysian Islamic Bank during 1984 -1997: An Explanatory Study. Thoughts on Economics, 10 (1\&2), 7-26.

Sebastian, O., \& Uremadu. 2009. Banking System Credits to the Domestic Economy and National Development. Annals of University of Bucharest, Economic and Administrative Series, 3, 149-16

Tomak. S. 2013. Determinants of Commercial Bank Lending Behavior: Evidence from Turkey. Asian journal of Empirical Research.

Wahidudin, A.Z., Subramanian, U., \& Kamaluddin, P. 2012. Determinants of Profitability- A Comparative Analysis of Islamic Banks and Conventional Banks in ASEAN Countries. $\quad 2^{\text {nd }} \quad$ International Conference on Accounting, Business and Economic, MS Garden Hotel, Kuantan Pahang; Malaysia.

Widagdo, A. \& Ika, S.R. 2007. The Interest Prohibition and Financial Performance of Islamic Banks: Indonesia Evidence. Paper presented in 19th Asian-pacific Conference on International Accounting Issues. Malaysia, Kuala Lumpur.

Zeitun, R. 2012. Determinants of Islamic and Conventional banks
Performance in GCC Countries Using Panel Data Analysis. Global Economy and Finance Journal, 5(1), 53-72. 